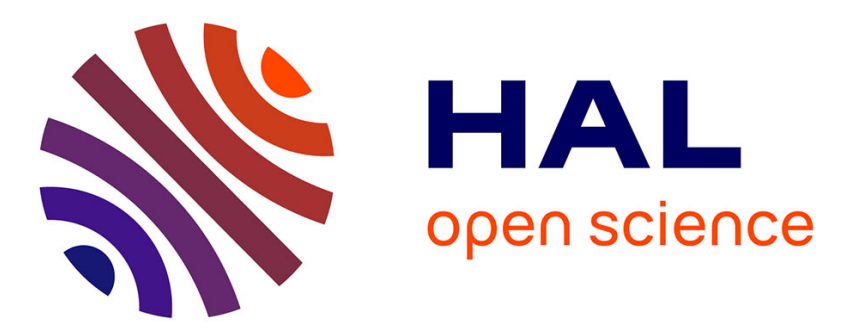

\title{
The political battlefield: negotiating space to protect indigenous and traditional knowledge under capitalism
} Janice Busingye, Wiebke Keim

\section{To cite this version:}

Janice Busingye, Wiebke Keim. The political battlefield: negotiating space to protect indigenous and traditional knowledge under capitalism. International Social Science Journal, 2009, 159, pp.37 - 54. halshs-01076968

\section{HAL Id: halshs-01076968 \\ https://shs.hal.science/halshs-01076968}

Submitted on 23 Oct 2014

HAL is a multi-disciplinary open access archive for the deposit and dissemination of scientific research documents, whether they are published or not. The documents may come from teaching and research institutions in France or abroad, or from public or private research centers.
L'archive ouverte pluridisciplinaire HAL, est destinée au dépôt et à la diffusion de documents scientifiques de niveau recherche, publiés ou non, émanant des établissements d'enseignement et de recherche français ou étrangers, des laboratoires publics ou privés. 
Keim, Wiebke; Busingye Janice Desire (2009): The political battlefield. Negotiating space for the protection of traditional knowledge in capitalism. In: International Social Science Journal (Special Issue on „Global Knowledge") 195, S. 37-54.

- Manuscript -

The political battlefield: negotiating space to protect indigenous and traditional knowledge under capitalism Janice Busingye and Wiebke Keim

\section{Abstract}

Knowledge has increasingly become an essential resource in the global economy, hence the capitalist tendency to regard it as a form of capital and as a motor for innovation and profit. Like any other capitalist commodity, conflicts over the ownership and use of various types of knowledge have arisen, thereby calling for legal protection. Nation-states as well as inter-state organisations are developing these legal frameworks in order to regulate the conflicts between different social actors. Consequently, thinking on knowledge and power has evolved to include the protection of knowledge from those who seek to gain control of it through the acquisition of legal rights, for instance, intellectual property (IP) rights. In many commercialised industrialised countries, legal frameworks have already been developed to protect IP. These include patents and copyrights as well as other trademarks, database rights and so on. However, in many developing countries with a weak technological base and less commercialisation IP protection mechanisms have not yet become firmly established. This is happening even though they have genetic resources and traditional knowledge that are of value to them and to the world at large. The protection of indigenous knowledge has existed as long as the knowledge itself, but the recognition of such mechanisms has been tightly controlled by stronger powers. In this article we argue that, whatever local communities choose to do to protect their indigenous knowledge, in the context of the current IP regime and the power of commercially driven global actors, the concept of traditional or indigenous knowledge itself becomes political. If the traditionality of knowledge can be reasonably questioned from an epistemological point of view, it would seem possible to claim rights and recognition for local communities in a highly controversial and economically relevant international arena.

\section{Biographical notes}

Wiebke Keim completed a PhD in sociology at the Universities of Freiburg in Germany and Paris IVSorbonne in France. Her areas of interest are the history and epistemology of the social sciences, African and Latin American sociological traditions, the sociology of science and knowledge and globalisation. She spent 3 months doing post-doctoral research at the University of KwaZulu-Natal in 
Durban, South Africa. She is currently affiliated to the Chair for Social Policy and Social Work at University of Fribourg in Switzerland and has teaching commitments at the Universities of Bern in Switzerland and Freiburg in Germany.

Email: wiebke.keim@web.de

Janice Desire Busingye is a PhD candidate at the University of KwaZulu-Natal in Durban South Africa. Her area of focus is epistemology, indigenous knowledge systems and livelihoods' security in the community development context. She has had teaching commitments at Makerere University, Uganda, for 7 years and is now concentrating on her PhD studies.

Email: babayika77@yahoo.com

There is no doubt that knowledge is becoming an essential resource in the global economy, as reflected by the development of terms such as information society or knowledge economy. As a result of the capitalist tendency towards commoditisation, knowledge is perceived to be a form of capital and as a motor for innovation and profit. Like many current political and economic conflicts, the conflict over knowledge claims, ownership and usage is increasingly channelled into legal frameworks. States as well as well as inter-state organisations are developing these legal frameworks in order to regulate the conflicts between various social actors. Consequently, thinking on knowledge and power has evolved to protection of knowledge from those who seek to gain control of it through the acquisition of legal rights, such as intellectual property (IP) rights. As a private right, intellectual property impacts different on groups in society in different ways. At the international level, IP rights are generally treated as economic and commercial rights and are usually held by companies rather than individual inventors. This has resulted in contested institutional arrangements at the national and international levels, as well as resistance to those legal, political and institutional arrangements (for a systematic overview, see Correa 2001, pp.20-27.) We conclude that, through these battles, the concept of indigenous or traditional knowledge, although debatable from an epistemological point of view, has gained in political significance.

\section{Intellectual property rights - protection for the benefits of the North?}

Many industrialised countries have already developed a legal framework for the protection of IP, including patents and copyrights as well as other forms such as trademarks and database rights. Alexander rightly points out that

describing them as "rights" should not be allowed to conceal the very real dilemmas raised by their application in developing countries, where the extra costs they impose may be at the expense of the necessities of life for poor people.... Too often, the interests of the "producer" dominate in the evolution of IP policy, and those of the ultimate consumer are either not heard or heeded. 
He continues: "In IPR discussions between developed and developing countries, a similar imbalance exists. Developing countries negotiate from a position of relative weakness. The difficulty is that they are 'second comers' in a world that has been shaped by the 'first comers'” (Alexander 2002, p.2.)

These legal frameworks have historically evolved as a policy measure to accompany and facilitate economic and social development. Many countries of the global South, however, have not put much emphasis on this area. Traditional responsibilities and roles, as well as current expertise in the domain of commercially relevant knowledge, do not always correspond to the patterns prevalent in industrialised countries. In the context of the countries of the global South the extent to which IP protection might serve as an incentive for autonomous scientific and industrial research, innovation and development is highly questionable.

The battle around IP has thus become increasingly problematic at the international level, where legal issues around IP protection are closely intertwined with economic, political, social and moral questions. Large industrial research and development companies, together with the governments of industrial countries, have been working towards a more coherent IP protection internationally for the last 20 years. The establishment of an international intellectual property regime by the World Trade Organization (WTO) members on trade-related aspects of intellectual property rights (TRIPS), agreed upon in 1995 and effective since 2005, is the backbone of the capitalist project of commoditisation of knowledge at an international level. Neutrally speaking, TRIPS strengthens the rights of knowledge owners by guaranteeing that all signing states protect the IP-rights granted in any other of the signing states. But others see it more critically: "TRIPS was designed to prevent so-called piracy by developing countries of the inventions and products of rich countries. But it is silent about the systematic appropriation of biological knowledge and informal forms of indigenous knowledge from developing countries by large Northern companies" (Oxfam 2002).

Under TRIPS' growing pressures for harmonisation, most developing nations are restricted in how they can form their IP systems. Tansey (2002, p.1) rightly states that TRIPS underpins the new knowledge economy in which the ownership and control of knowledge affects the distribution of wealth and power. This has led to lively debates stemming from philosophical and moral reflections on the privatisation of knowledge to more political and economic arguments concerning the inequalities between countries of the global South and the global North (See Pardey and Wright 2001). Basically, the global distribution of central factors for the commercial use of knowledge, such as scientific institutions as well as multinational firms, are highly centralised and have not protected indigenous or traditional knowledge. Science and innovation systems in most developing countries are weak, and the development of these capacities takes time. It will certainly not be achieved by immediate extension of IP rights (See Correa 2002). For instance, 90 per cent of all research and development as well as most patents, as the economically most relevant form of IP, are concentrated in the North. According to the OECD (2005) patent database the EU27 held 43 per cent, the USA 26 per cent and Japan 16 per cent of the global share of patents. Critics therefore argue that TRIPS 
unilaterally protects the interests of the producers and exporters of IP products from the North, to the detriment of IP importing countries and populations of the global South.

The Committee on Intellectual Property Rights (CIPR) was created in order to investigate the relations between IP and development, with a special emphasis on the situation in the South. The committee's report, “Integrating Intellectual Property Rights and Development Policy” (CIPR 2005). The committee's press release was entitled: "Independent Commission finds IP rights impose costs on most developing countries and do not help reduce poverty" (CIPR 2002). The report draws a complex picture of the situation, but fundamentally confirms that poorer countries are generally disadvantaged by the existing legal framework. ${ }^{1}$ In particular, the CIPR discourages developing countries from providing patent protection for plants and animals through TRIPS regulations, pointing out that patents may, for exampl,e restrict the use of seeds by farmers and researchers.

Looked at more closely, economic and power inequalities between North and South emerge at three levels: (a) in setting priorities in research and development, (b) in access to IP-products and (c) in the use and recognition of commercially relevant knowledge.

On the first point, the problems of the global South are often neglected by major research and development agents as they do not provide a profitable market for them. This is apparent, for example, in the fact that medical research deploys much more capacity on investigating the diseases of the rich, for instance, obesity, than the diseases of the poor, such as HIV/AIDS, malaria and tuberculosis. Less than 10 per cent of global medical research focuses on 90 per cent of diseases.

With regard to the second point; access to and use of IP products, it seems obvious that higher prices for products due to patent rights make it not only more expensive to access not only medical care, but also agricultural products such as seeds, computer and information technology and educational materials. Deardorff (1992) uses an economic model of invention and patent protection and examines the welfare effects of extending patent protection from the inventing country to a country that consumes the invented products. He arrives at the conclusion that while the welfare of the inventing country rises, that of the recipient country probably decreases and may well fall by more than the increase in welfare of the inventing country. Similarly, Panagariya (1999) demonstrates through economic analysis that the TRIPS Agreement is a welfare-reducing proposition not only for developing countries but the world as a whole. He foresees an increase in the monopoly power of the North without incentives for research and development in the South. The Commission on Intellectual Property Rights, (n.d.) for instance, has commissioned various studies on disadvantages for poor countries in the domain of health. In addition, the South Centre in Geneva is producing studies confirming the disadvantages of the global South in the area of digital media.

In the following, we will focus on the third point, that is, the use, effective protection and recognition of commercially relevant knowledge. Kraak (2000, p.74) argues that the main issue at stake is no longer the question of access to knowledge, but the control of marginal additions to a particular body of knowledge. We choose as an example the status of indigenous medical knowledge 
in Mexico and Uganda. ${ }^{2}$ We highlight two possibilities of protecting this traditional knowledge from the interests of commercial users based in the North. First we explore possibilities of protection through adherence to the logic of the IP regime; then we focus on community forms of protection in Uganda and Mexico.

\section{Indigenous and traditional knowledge - epistemological and political issues}

A fairly complete attempt at definition of indigenous knowledge, based on an extensive literature review, is given by Ellen et al. (2000). This definition can be used as a starting point here. The three authors define indigenous knowledge as knowledge that is local, orally transmitted and elaborated over generations through practical experience of trial and error. Therefore it can be characterised as "empirical and empirico-hypothetical knowledge rather than theoretical knowledge in the strict sense" (p. 1). Indigenous knowledge is redundant in the sense that it is frequently reiterated, negotiated and constantly changing, yet it is often perceived as rather static and it is widely shared yet distributed according to social stratification along lines of gender and age, among political or ritual authorities and specialists, etc. Furthermore, it is distributed in fragmentary ways, i.e. no conservatory exists where it is contained in its totality. Indigenous knowledge is organised in functional terms, i.e. it is "denotative 'know-how geared to practical response and performance" (Ellen et al. 2000, pp.4-5).

For the purpose of this article, the term indigenous knowledge can be used synonymously with the term traditional knowledge, although it would appear that traditional knowledge is the more encompassing term. Practically all knowledge that is not scientific, according to modern science, can be subsumed under this label. It is, first of all, a thematically encompassing term covering, among other things, music, moral principles, child rearing and education, medical formulae, technical knowledge, categorisations of plants or animals, transmission of historical experiences, magical knowledge, religious and ritual oral texts, agricultural know-how and gardening skills, cooking recipes and textile designs. ${ }^{3}$

Furthermore, the term traditional knowledge refers to types of knowledge that are very different, for example, in terms of their location, scope, distribution, ways of transmission and inherent complexities. According to location, the term local knowledge as one sub-field of traditional knowledge, refers to rather small areas of distribution, such as, but not exclusively, the knowledge of rural or peasant communities. The terms indigenous or endogenous knowledge are similar and are often associated more particularly with the countries of the global South (for problems particular to the situation in the global South, see below.)

The more general categories of folk or common knowledge may also be subsumed under the broad term of traditional knowledge, that is, it is rather broadly distributed, non-professional, uncodified, and experiential or ad hoc knowledge that is often orally transmitted. The term common knowledge does not contain any reference to location.

Tacit knowledge may also be included under the category of traditional knowledge. Tacit knowledge means non-explicit and somewhat intuitive knowledge that is acquired through experience 
and cannot easily be transmitted. These forms of knowledge exist at the very individual level or in the small communities where they are practiced. In the French debate it is also referred to as hot knowledge. Tacit knowledge is thus opposed to the idea of common knowledge.

Yet it is obvious that, according to the overall definition by Ellen et al. (2000), the term indigenous encompasses other forms of knowledge that appear to be the opposite of common knowledge, like professional, specialised knowledge, which is often highly systematised, formalised, either orally transmitted or documented and generally restricted in distribution, as, for instance, medical knowledge but also religious, mythical and some historical knowledge. As a consequence, the terms indigenous or traditional knowledge seem to dissolve under the variety of their sub-fields. Hence it might justifiably be asked whether, from the epistemological point of view, such broad terms are at all useful and meaningful. ${ }^{4}$

Beside their highly questionable epistemological status - there are almost no positive common characteristics between these subcategories - the terms entail problems at the imaginative, metaphorical level. Traditional knowledge is likely to be associated with traditional communities whatever this might be - thus deepening the imaginative gap between modern and traditional societies. The term might furthermore be associated with the static character of this knowledge. Both associations are problematic.

Defenders of the denomination of knowledge as traditional may argue that it is meaningful as an oppositional term. ${ }^{5}$ While scientific knowledge is a body of internally consistent, uncontested and impersonal knowledge, claiming universality, traditional knowledge claims locality not universality. This leads to a more general questioning of the possibility of universal knowledge and to the relativism-rationalism debate, which we will not deal with here. However, the argument around oppositionality shows that the epistemological argument is rarely isolated from a political argument. Proponents of traditional knowledge and critics of modern scientific knowledge argue that modern science became supposedly universal for extra-scientific and non-scientific reasons, namely, economic and geopolitical parameters.

At this point we come back to the particular situation of the countries of the global South, more specifically Africa and Latin America. It does make sense to distinguish their situation from the North Atlantic countries. In the South, the origins of scientific knowledge were not an endogenous development but historically imported from the (former) colonial metropolises and imposed onto the local context. This importation often implied re-importations of elements of knowledge that had been extracted by colonial and post-colonial agents and incorporated into scientific knowledge in research institutions and laboratories based in Europe (Hountondji 1994). The origins of these dislocated knowledges are then hidden by the anonymous research process and by their presentation in the generalised idiom of modern science.

In this context the term traditional knowledge - here equated with indigenous knowledge acquires a cultural meaning. Native populations consider indigenous knowledge to be part of their own 
cultural identity and to be a very concrete and politically appropriate way of asserting it. As Ellen et $a l,(2000$, p. 22) put it: "Part of the reason for this is that, although the guardians of such knowledge are traditionally oriented individuals and groups, those who wish to document it are from westernised elites or other outsiders. A very important relationship of unequal power is thus articulated". The colonial experience, where local types of knowledge were denied, marginalised, oppressed and nearly destroyed, adds to the moral, cultural and political significance of what are perceived as current neocolonial practices of appropriation of indigenous knowledge nowadays (see below).

The term traditional, in the sense of indigenous or endogenous, in opposition to modern science, has a different meaning here than it has in the North Atlantic domain. It is clear, however, that we are dealing with a political rather than an epistemological term. Apart from the fact that the knowledge referred to as traditional in such contexts is not subsumed under modern scientific knowledge, the characterisation, traditional, does not tell us much about it. This remains problematic in the sense that the characterisation is possible only in opposition to modern science, so the latter thus remains the dominant reference point. This restricts the analysis of traditional and indigenous knowledge by "narrowing the parameters of understanding through the imposition of western categories" (Ellen et al. 2000, p.14).

We argue in the following sections that traditional and indigenous knowledge can gain a much more concrete and pragmatic meaning when used as political categories in a precise constellation of interests that arises out of the capitalist use of commercially relevant knowledge worldwide. In this political battlefield, the term traditional or indigenous knowledge defines the position of those who claim to be its authors, inventors or owners and thus to have rightful and unrestricted use of these types of knowledge.

\section{Access to and use of commercially relevant traditional knowledge: the option of adherence to the logic of the IP regime}

Although most developing countries do not have a strong technological base, they do have genetic resources and traditional knowledge that are of value to them and to the world at large. This gives rise to a further key question. Can the "modern" IP system help to protect these resources of knowledge and ensure that the benefits of their use are equitably shared? (Alexander 2002, p.2) Alexander's question suggests exploring ways in which adherence to the logic of the IP system can help protect traditional knowledge in the countries of the South. In order to do so, it is necessary to clarify firstly, what is meant by traditional knowledge in a legal sense; and secondly, what is meant by protection. The definition of traditional knowledge used by the World Intellectual Property Organization (WIPO) seems to capture essential features regarding the necessities of the IP regime:

WIPO currently uses the term "traditional knowledge" to refer to tradition-based literary, artistic or scientific works; performances; inventions; scientific discoveries; designs; marks, names and symbols; undisclosed information; and all other tradition-based innovations and creations resulting from intellectual activity in the industrial, scientific, literary or artistic fields. "Tradition-based" 
refers to knowledge systems, creations, innovations and cultural expressions which: have generally been transmitted from generation to generation; are generally regarded as pertaining to a particular people or its territory; and are constantly evolving in response to a changing environment. It should be emphasized, however, that a precise definition of traditional knowledge is not a crucial requisite for establishing a system for its protection.... The crucial element for the protection of any subject-matter is the identification of some characteristics that it must meet as a condition for protection - such as novelty, inventiveness and susceptibility of industrial application, for inventions, and distinctiveness, for trademarks. The same criterion could be applied to traditional knowledge as well. (International Bureau of WIPO 2002)

In the discussion of traditional knowledge and its possible protection through adherence to the IP regime, the concept of protection is used in highly ambiguous ways. First of all, the legal concept of protection, that is, conferring rights over traditional knowledge, has to be distinguished from protecting this knowledge in the sense of preserving it from destruction or loss or encouraging its use through other mechanisms than IP. (Correa 2001, p.10.) We are dealing here with legal issues around protection through IP rights, where "protection essentially means to exclude the unauthorised use by third parties" (Correa 2001, p.5).

More importantly, regarding the protection of knowledge through IP rights, the question is to whose advantage can IP be used and what one is actually trying to protect, as well as in whose interest. While traditional knowledge gains in importance and recognition, major research and development agents, in particular in the field of medical and pharmaceutical research, have treated it as information in the public domain, freely available for use by anybody. This has led to cases where traditional knowledge has been appropriated - "protected" under IP rights - by researchers and commercial enterprises without compensation or the consent of the creators or possessors of that knowledge. This is usually referred to as piracy or, in the specific case of biological substances and associated knowledge, bio-piracy. ${ }^{6}$

Consequently, the thinking on possible ways to protect indigenous knowledge depends on the concept of protection as well as on the perspective adopted. We consider the issue here from the perspective of the holders of traditional knowledge in terms of the protection of their knowledge against unauthorised appropriation by external agents. The threat of bio-piracy has been taken into account in the statements of IP experts who suggest that adhering to the logic of IP can provide several ways of protecting traditional knowledge against unauthorised exploitation by others, especially commercial R\&D companies. Before we look more closely at these legal possibilities, the main reasons for protection of this form of knowledge apart from the threat of bio-piracy should be briefly mentioned.

As Correa noted, these reasons comprise first of all what he calls equity considerations. This point is closely related to the argument around bio-piracy: "Traditional knowledge generates value that, due to the system of appropriation and reward currently in place, is not adequately recognised and 
compensated. The protection of traditional knowledge would, therefore, be necessary to bring equity to essentially unjust and unequal relations" (Correa 2001, p.5). This refers mainly to the fact that the communities who are holders of traditional knowledge are not compensated for the value they deliver, since companies who commercially use their knowledge are not charged a price for the samples they acquire and do not share later benefits arising from the commercialisation of the product. Some legal protection of traditional knowledge could thus lead to more equitable relations between those who hold and those who acquire it.

Furthermore, according to Correa, protection through IP provisions in the interest of the original holders might help conserve their knowledge, as well as their traditional lifestyles, as a central element of the cultural heritage of humanity. Finally, some proponents argue it might promote assignment of value to the use, development and application of traditional knowledge.

It may be argued that protecting TK against loss and misappropriation, or ensuring compensation

to TK [traditional knowledge] holders, are necessary elements to stimulate the broader use of such knowledge. Protection may be, in this context, a tool for facilitating access to TK. Some form of protection may create the basis of trust required for the local/indigenous communities to part with their knowledge, and improve their position to obtain value from it. If some rights were recognised, knowledge holders may be more prepared to provide access to their knowledge and, if fairly compensated, they will have more incentives to conserve it and ensure future access. (Correa 2001, p.8.)

However, as already outlined above, protection through IP rights can have the ambiguous effect of promoting as well as reducing access and utilisation of the protected knowledge. While the actions discussed below are based on very broad suggestions by legal experts, it has to be kept in mind that there are many culturally and socially diverse communities and individuals worldwide that hold the knowledge in question. It seems impossible to identify the concerns of intended beneficiaries of new systems of protection in a general way. For many local communities the mere idea of IP as a monopolistic right in itself might be essentially in contradiction to their belief systems and practices. In the following, several forms of protection through adherence to the logic of the IP regime are briefly outlined.

\section{Protection of traditional knowledge through IPR}

Some components of traditional medicine are suitable for protection under patent laws. In several cases, patents on natural substances have been granted, as well as on their combinations for medical use. Correa argues that especially in the area of traditional medicine, control of knowledge through IP rights might be acceptable and even desirable. As he shows in his chapter on community protection of medical knowledge in Uganda, in many cases medical knowledge is controlled and access to it is reduced in the community setting as well, indicating that concepts close to individualised rights and exclusive access might be prevalent in these communities. 
A major legal obstacle for a generalised protection of traditional knowledge through patenting in the interest of its original holders, apart from many practical questions, is the fact that this knowledge often does not fulfil the conditional requirements of novelty but has been in use for long periods. Plant materials and their medical use are only patentable if they are novel inventions. At that level the international IP regime is clearly to the disadvantage of traditional knowledge holders. While several national laws (Mexico, Argentina and the Andean Group) exclude, for example, the patentability of all genetic materials on the grounds that they are not inventions, patent laws in the EU and USA allow for the protection of isolated or purified forms of a natural substance, including genetic material (Correa 2000, p.16). Consequently, the possibilities for patenting of given substances in these Latin American countries are limited by the legal framework and by the capacities of communities to further develop their know-how into knowledge in accordance with the standards and requirement of modern science.

More generally, this raises another major concern, namely that national IP systems cannot address problems of bio-piracy, as a third country might grant the patent in question: "Since the granting of patents is dependent on each national law, the non-patentability in one country does not mean that traditional knowledge could not be patented in another country without the authorisation of the communities that developed or possessed that knowledge" (Correa 2000, pp.28-29). In this case however, it is possible to contest the patent claim on the grounds of prior art.

\section{Prior art, cataloguing of traditional knowledge and disclosure of origin}

IP rights are basically intended to protect novel inventions. Under IP regulations, traditional knowledge can be declared "prior art" - that is, knowledge already in the public domain or, more precisely "all public knowledge before the priority date which could be relevant to the novelty or unobviousness of an invention" (Correa 2001, p.7.) This means it becomes impossible to claim IP ownership over this form of knowledge and it has to remain accessible without legal restrictions.

Correa thus suggests that the countries concerned proceed towards cataloguing existing knowledge over, for instance, medical plants and their curative usage, in order to be able to take action against pharmaceutical companies that might claim patent rights over this knowledge and the plants in question. This presupposes the consent of the concrete holders of the knowledge, who are, in fact, seldom countries but, as examples cited below illustrate, specific communities, small groups of initiates or even individuals; an issue Correa does not address in any detail. This would also require, as the CIPR demands, that patent applicants have to disclose the geographical source of vegetal substances as well as associated knowledge from which their invention is derived: "In this way, developing countries can be informed of proposed patents that incorporate their resources and take action if their rights have been overlooked.... Examiners who weigh the validity of patent applications could then check claims of 'invention' against existing traditional knowledge" (CIPR 2002).

Ramesh Mashelkar, one of the CIPR commissioners and Director General of the Indian Council of Scientific and Industrial Research (CSIR), gives the successful and often cited example of India's experience with invalid patent claims on turmeric as a medicinal plant (CIPR 2002). In fact, the CSIR 
had contested US patent No. 5,401,5041, which was granted for the wound-healing properties of turmeric and asked for a re-examination. The US Patent and Trademark Office had to confirm that the novelty requirement was not met, as turmeric had been used for healing in India for centuries (Correa 2001, p.7). This is all the more surprising and encouraging as US legislation does not recognise prior art of knowledge produced outside US borders: "According to section 102 of the US patent law, information that has been published in a written form in the USA or in any other country is not patentable. But if the information was publicly used but not documented in a foreign country, novelty is not lost" (Correa 2001, pp.7-8). India has started a database of documented traditional knowledge in the domains of Ayurveda, Siddha, Unani, Yoga, Naturopathy and traditional medicine which is already in the public domain, and is known as the TK Digital Library. (Council of Scientific \& Industrial

\section{Research (CSIR)( Department of Ayurveda, Yoga \& Naturopathy, Unani, Siddha and Homeopathy}

(AYUSH)). Such databases can be used by patent offices that are checking the status of novelty of submitted patent claims.

In order for such a provision to work, however, it is also necessary for patent claims to be accompanied by a declaration of the origin of substances and knowledge about the use in question. This would not only allow for examination of novelty, but could also lead to procedures provided through the Convention on Biological Diversity (CBD).

\section{Benefit sharing through the CBD}

The CBD, agreed upon during the 1992 Earth Summit in Rio de Janeiro and signed by 168 countries, contains a benefit-sharing principle under articles $8(\mathrm{j}), 15,16$, and 19. Instead of the establishment of a system of positive appropriation, these articles state, among other things, that the CBD aims at promoting the wider application of the "knowledge, innovations and practices of indigenous and local communities ... with the approval and involvement of the holders of such knowledge, innovations and practices and encourage the equitable sharing of the benefits arising from the utilisation of such knowledge, innovations and practices" (CBD 1993, Art. 8j). Concerning the commercial use of genetic resources more specifically, the CBD states:

Each Contracting Party shall take legislative, administrative or policy measures ... with the aim of sharing in a fair and equitable way the results of research and development and the benefits arising from the commercial and other utilisation of genetic resources with the Contracting Party providing such resources. Such sharing shall be upon mutually agreed terms. (CBD XXXX, Art. 15.7)

Furthermore, article 19 is relevant in this field:

Each Contracting Party shall take all practicable measures to promote and advance priority access on a fair and equitable basis by Contracting Parties, especially developing countries, to the results and benefits arising from biotechnologies based upon genetic resources provided by those Contracting Parties. Such access shall be on mutually agreed terms. (CBD XXXX, Art. 19.2)

The CBD is thus an important document that aims at regulating the access to and sharing of benefits of the commoditisation and commercialisation of plant material and knowledge of its use in 
the international arena. Its provisions might prove more effective to protect the interests of traditional knowledge holders than to encourage positive adherence to the IP regime, for example, through patent claims. Currently however, the CBD and the TRIPS agreement are not in complete accord regarding these points. The government of India, for instance, has proposed, as a way to more closely align the TRIPS Agreement with the CBD, to incorporate in the Agreement a provision establishing that patents inconsistent with Article 15 of the CBD must not be granted (Correa 2001, p.10).

Further ways of protecting traditional knowledge mentioned by IP experts are the establishment of sui generis regimes. A model of sui generis national legislation that would give communities propertylike rights over their collective knowledge was developed by the Third World Network (Community Intellectual Rights Act) in 1994 (see Lewis \& Clark Law School n.d.). Such legislation would also reinforce customary law, tribal, communal or community intellectual rights, and traditional resource rights, etc., that are not seen as being in conflict with the TRIPS agreement. For instance, the draft Biodiversity and community knowledge protection Act of Bangladesh prohibits the violation of common property regimes, which include various rights, relations, arrangements and cultural practices, whether or not they have legal expressions or recognition, by which communities own, use and have access to biological and genetic resources (Correa 2001, p.15).

To conclude, Correa rightly points out that the legal side should not be overemphasised in a context where many communities are unable to preserve and exercise their traditional knowledge and associated practices due to economic, social, political and environmental constraints and lack of control over resources (Correa 2001, p.10).

\section{Community ways of protection in Uganda}

Indigenous communities have had their own ways of protecting and keeping their knowledge in their communities. With increased commoditisation and marketisation of knowledge under capitalism, these systems have been referred to as hindrances to the wider usage of such knowledge. Although the protection of traditional knowledge in the globalisation era has become more apparent than before, there are wider implications for local ways of protecting traditional knowledge that may stifle traditional protection mechanisms for good, with no ready alternative.

In Uganda, for several reasons, indigenous knowledge is an important component of the healthcare system, currently serving up to 80 per cent of the total population. (Biachi 2004; Uganda National Council for Science and Technology [UNCST] 2006.) Indigenous knowledge in Uganda fills the gap created by poor access to modern health services and people in their communities also believe in the remedies that have worked for them for a long time. This realisation became even more apparent when Uganda was faced with the HIV/AIDS pandemic, because many people were visiting traditional healers (TH) even when they were not getting any curative remedies. Some TH claimed they had discovered the cure for HIV/AIDS and people visited their shrines out of desperation. At the policy level, THs were getting recognised for their contribution to the treatment of some opportunistic infections related to HIV/AIDS. As a result, in 1992 a non-governmental organisation (NGO), 
Traditional and Modern Health Practitioners Together against AIDS and other diseases (THETA) was established. Based in Kampala with several branches in the districts, its major purpose is to organise, monitor and supervise activities between herbalists or THs and modern healthcare providers (THETA 2005). THETA has worked with and trained THs and herbalists and has helped them document their knowledge. With the documentation of their remedies, a new concern has emerged regarding the lack of a mechanism to protect the THs' remedies against piracy. Currently, THETA operates a medical clinic where the THs and bio-medical workers diagnose and treat patients concurrently. The Ugandan government has been in the process of producing a policy to regulate the use, production and protection of indigenous knowledge since 1992, but to date it has not succeeded in making it law. While legislation is still being formulated, THETA reveals that the THs it works with have their own forms of protection which have been successfully passed on from one generation to the next. The following section gives a description of such methods. These paragraphs are based partly on informal conversations with THs and herbalists and THETA field workers in August 2007; and partly on experience from a research project on traditional medicine, mental health and HIV/AIDS in Kampala District, Uganda, that I was involved with in 2005.

\section{Orality}

One of the reasons people claim that local knowledge is hard to protect is that it is oral and is passed on from one person to another. The US government has argued that due to the oral nature of indigenous knowledge, it is not available to benefit the public because it relies on face-to-face communication, thereby limiting access to it (Correa 2001). However, Ellen and Harris (2000) observed that, with documentation, the very essence of the indigenousness of local knowledge will be lost because then it will no longer be generated and applied to the local situation. While these arguments are appreciated in their own right, the THs in THETA maintain that they keep their knowledge oral because then no one can know it and use it to treat other patients. To achieve this, they make sure that they reveal only the part that will not lead any other person to the ingredients they used to make a particular remedy. While this might be conceived as selfishness, Pottier et al. (2003, p.17, quoting James Scott's 1990 "Hidden transcript") show that, in a sphere where there are inequalities, people always reveal what they feel it is safe to reveal. He adds that the amount of information revealed usually depends on the disparity in power. Thus, THs ensure that new discoveries are known by themselves and passed on only to another chosen individual in the next generation. Documentation in this case would threaten the secrecy of the TH's practice. Such concerns, whether founded or not, work against documenting local knowledge. Unlike other countries that have already established their legal frameworks on IP rights, Uganda is still in the process of formulating one regarding indigenous knowledge, so the only protection mechanisms they have are the indigenous ones already in place.

\section{Spiritual revelation}

Some of the knowledge, especially that for healing, is looked upon as a special gift in the communities where the THs live and practice, commonly referred to as necromancy (the act of consulting ancestral 
spirits for diagnosis and treatment: for more, see Nyika 2007, p.2). In communities in Uganda THs maintain that their ancestors are the ones who diagnose the kind of disease one is suffering from and prescribe the remedy. They believe that the revelation comes through spirits (empewo) in a special session that is attended only by the TH. This ensures that no other person can ever know what the remedy is or how it is supposed to be mixed and administered. In order to keep it going from one generation to another, the holder reveals it to a younger person designated by the ancestors. Such a person is apprenticed to the THs in order to learn all about the remedies they use. This allows the remedy to be administered without questioning its origin or method of preparation, because the hands that prepare it are guided by those of higher powers. This keeps it safe, in that only the one that has been chosen by the ancestors knows it. Such individuals are accorded special status in the family because they represent those who have died, commonly called Jajja (meaning grandparents). When all these guidelines are followed, no one other than the specially chosen ones will have access to such knowledge, hence protecting it from piracy.

\section{Setting tight rules regarding the picking and administering of medicines}

THs revealed that they have strictly followed guidelines regarding picking and administering certain drugs that also serve as protective mechanisms against piracy. For example, they say that some herbs are not supposed to be picked early in the morning, late in the afternoon or immediately after it has rained. What some of them are trying to avoid is any other members of the community tracing their footsteps back to a particular plant in the bushes. For example, they said that if there is dew in the morning, that might lead someone to the place where the plant was picked, so they decide not to pick the medicine during that time. Such guidelines also serve as protection mechanisms. They warn that if these guidelines are not followed, the medicine will not work. For example, a TH may administer a drug very early in the morning before anyone else is awake. There is medication for a swollen spleen (ekibare) where the patient is given small cuts on one side of the stomach and the drug is applied to the cuts. I was told that it can only be administered early in the morning before the cock crows. But the TH revealed that this is to protect the knowledge from anyone who might want to copy it.

\section{Preparation of medicines}

It has been observed that many THs make their drugs are made available only in the final, prepared state in which they are supposed to be consumed, in powder, paste or liquid form. The patient will not know what original substances were used to compose the medication they are given. If you ask for the original substance, are treated with suspicion, as a potential thief who wants to produce the remedy for yourself. The THs also tell the clients that they pick the remedies far away from where they live, often asking for advance time in order to make the required medicine. This form of protection keeps the patient ignorant about the medication they are receiving and protects the THs' formulas against piracy, with the assurance that the patient will come back if the illness reappears. The THs are always convinced that their medication will work for any diagnosed illness. 
These are some of the methods used by THs to protect their knowledge from possible piracy. Seen in another way, however, these are the skills they have adopted over a long period of time to retain control over their own knowledge, in an environment where accumulation of wealth, intellectual or otherwise is salient. The THs wield social, economic and political power in their societies by virtue of their status as THs, and they are not willing to give it up at any cost. Unconsciously or consciously, the THs are well aware of the relationship between the power and knowledge they hold in their communities. The methods they use are therefore not just simple means of keeping knowledge to themselves; they also ensure that they retain control over such knowledge.

\section{Mexico: successful resistance to the International Cooperative Biodiversity Groups (ICBG)-}

\section{Maya project}

Mexico hosts a one of the richest biodiversities in the world. The tropical forests of Chiapas are of particular interest to pharmaceutical firms and research institutes. Various projects to screen this biodiversity and extract biological and genetic substances for industrial development of drugs (bioprospection) have been initiated in the country during the last 15 years (Barreda 2000) and resistance to these efforts has arisen simultaneously. The following focuses on one example of successful resistance that shows how indigenous health professionals defended their rights to their knowledge and natural substances.

In 1991 the US government paved the way for massive bio-prospection through so-called International Cooperative Biodiversity Groups (ICBG), a programme co-funded by the US Institute of Health, the National Science Foundation and the US Department of Agriculture (Boutorabi and Scheinemann 2003. For further information, see International Cooperative Biodiversity Groups (n.d.) The goals of ICBG are follows:

The ICBG program aims to integrate improvement of human health through drug discovery, creation of incentives for conservation of biodiversity, and promotion of scientific research and sustainable economic activity that focuses on environment, health, equity and democracy....

Projects include acquisition and analysis of natural products derived from biological diversity as potential therapeutic agents for diseases of concern to both developed and developing countries. ICBGs are mainly intended for countries of the global South. The "Drug Discovery and Biodiversity among the Maya in Mexico", or ICBG-Maya, initiated in 1998, was sponsored by the University of Georgia, USA, the "Colégio de la Frontera Sur" (ECOSUR), Mexico, as well as a biotechnology firm, Molecular Nature Ltd in the UK (for details on the project see Castro Soto 2000, and from the opposed perspective of the project researchers, Berlin and Berlin 2003). For the planned duration of 5 years it was allocated a budget of US\$2.5 million. According to the internal division of labour, ECOSUR was in charge of the collection of plants, in collaboration with the indigenous communities, the US-based university was to tests and analyse the plant material and any positive results and substances identified for medical use were to be transferred to the UK-based firm for genetic sequencing. 
Although the US has not signed the CBD, the project was intended to conform to the CBD's requirements for mutual agreement and benefit-sharing. For this purpose, ICBG-Maya created its own counterpart, the Protección de los Derechos de Propiedad Intelectual de los Mayas Asociación Civil (PROMAYA), headed by the director general of ECOSUR, which was supposed to represent the interests of the local, indigenous civil society. The communities who contributed to the collection of plants, on condition that they signed an agreement with ICBG-Maya, were supposed to receive 0.25 per cent of the royalties funelled through PROMAYA, which would decide on the concrete allocation of the funds obtained in this way.

The project mainly aimed at the extraction of biological materials. THs insisted, however, that the indigenous knowledge on medical utilisation of plants serve as a guideline in identifying the plants that the project was going to deal with. It is estimated that the Maya traditionally use up to 6,000 species for medical purposes (Ceceña 2000). The healers' association also states that ICBG-Maya was exerting pressure on THs in order to obtain information (COMPITCH n.d.).

\section{Mobilisation of resistance}

The main actor that opposed the project on behalf of the indigenous THs was the Consejo Estatal de Organizaciones de Médicos y Parteras Indígenas Tradicionales de Chiapas (the State Council of Organisations of Traditional Indigenous Healers and Midwives of Chiapas"), or COMPITCH, initially founded through an initiative of the National Indigenist Institute. Meanwhile it has become the umbrella NGO of 18 organisations representing around 100,000 indigenous professionals in the domain of herbal and medical knowledge and practice. COMPITCH, as well as many of its member organisations, has made the protection of indigenous knowledge and of medical plants against biopiracy one of their objectives. Others include the promotion and further development of traditional medical knowledge, initiatives to gain more recognition for the profession, production of medical plants and their processing into curative substances, development of training materials and various other activities (see, for instance, Organisation of Indigenous Healers of the State of Chiapas [OMIECH], n.d.) COMPITCH had been approached by ECOSUR in 1998 and was asked to participate in ICBG-Maya but was not interested. Representatives stated that they later found out that full information on the project had not been disclosed on that occasion. For example, they had not been told the project planned to patent substances that were of commercial value for industrial production (COMPITCH n.d.). In the following years COMPITCH organised resistance against bioprospection.

In its campaign against ICBG-Maya, COMPITCH had two major international allies, namely the Canada-based NGO action group on Erosion, Technology and Concentration (the ETC Group), formerly Rural Advancement Foundation International, and the international human rights NGO Global Exchange. There is no doubt that the particular status of the state of Chiapas favoured resistance to the ICBG-project. Chiapas is certainly one of the poorest and most economically, socially and politically marginalised regions of Mexico. However, the uprising of the Zapatista movement and 
its powerful, publicly articulated anti-neoliberal and anti-neocolonial discourse, which has gained a vast national as well as international audience, has placed the southern state in the spotlight of resistance against neoliberal globalisation worldwide. A variety of NGOs and of local political and civil society movements, many of them linked internationally, have established consistent and reliable alternative media and international solidarity networks. COMPITCH itself acknowledges the contribution and benefit its struggle has drawn from the achievements of the Zapatista movement (COMPITCH 2002a).

COMPITCH also sought the intervention of the Secretary for Environment, Natural Resources and Fisheries (SEMARNAP) (see Valadez 2000). A tripartite negotiation table was established, with the participation of indigenous delegates, delegates of ICBG-Maya and authorities of SEMARNAP, the National Ecology Institute and of the National Biodiversity Commission. COMPITCH rejected each of the solutions proposed by the negotiators for various reasons, but primarily because the Council did not consider itself the appropriate and legitimate representative organism for all the indigenous communities concerned, and asked for a more democratic decision-making process that respected the communities' ways of political representation.

In 2000 ICBG-Maya failed to get regulatory approval from the Mexican government for making bio-assays on the plant materials collected (ETC Group 2001). In the same year a meeting of various NGOs, civil society and students' organisations called for a moratorium against the bio-prospection project. The news release of ETC Group at the occasion of the project cancellation relates the developments following the moratorium:

The ICBG Maya Project was staunchly defended by its director, anthropologist Brent Berlin of the University of Georgia. Failing to win consensus at the local level, and facing increasing criticism internationally, Berlin sought to redesign the project and salvage it. In August 2001 Berlin proposed to ECOSUR ... a re-designed project ... the advisory board of ECOSUR rejected it. On 7 October 2001, perhaps in a last-ditch effort to win approval for the project, a representative from the US Embassy in Mexico travelled to Chiapas to meet with representatives from COMPITCH, the indigenous group in Chiapas most active in protesting the project. Again, the local communities said no (ETC Group, 2001).

After ECOSUR withdrew from the project, the US government had to announce that ICBG-Maya was definitely cancelled.

\section{Resistance: main arguments against the project}

The criticisms against ICBG-Maya that led to such broad resistance can be summarised under the following arguments:

Lack of legitimacy and legality. The project did not conform either to Mexican or international legislation in terms of access to and utilisation of biological and genetic resources. ICBG-Maya was designed in the US without information and consent by the indigenous communities concerned, and without regard for Mexican national sovereignty (see Castro Soto 2000, p.21). An agreement on IP 
was signed covering the vital resources of the indigenous communities, but without the notification or consent of those concerned. Therefore it did not respect national legislation that established the need for prior informed consent by the communities, as well as for legal authorisation. It also disregarded international legislation (article 8(j) of the CBD XXXX). Lack of transparency was also criticised, as full information was not disclosed to all concerned. Among others, COMPITCH stated that they found omissions in the translation of the original English agreements into Spanish (COMPITCH n.d). In addition, the communities that had agreed to collaborate with ICBG-Maya and eventually showed project agents a variety of plants had been persuaded to participate through illegal methods.

COMPITCH stated:

The majority of the communities that we know of who have contracts with ICBG did not know about these questions [about the intention to patent substances and so on; WK]; they did not even know that the US was part of the project. What they were told was "collect a huge amount of plants, because we will solve all your health problems." They asked them what illnesses they had and the illnesses that were mentioned were exactly those that they were going to remedy with the plants. "In addition, we will give you a tip for collecting plants, we will take them to a laboratory in England, we will make good medicine out of them and we will then bring you this medicine." "If you want, you can later sell it." And they gave them a shoe box with the symbol of the Peso so they would understand they would earn money.... The communities were not informed, not even that it was a gringo project, to which they would have been very sensitive. Therefore, when we showed them the document [the ICBG-agreement], it was easy to convince them to reject the project. (COMPITCH n.d.)

It was also felt that the ICBG-Maya took advantage of the difficult economic conditions of local communities and bought individual informants in exchange for small amounts of money or other goods (statements by spokespersons of COMPITCH in Ceceña 2000, pp.191-196.) Furthermore, plants were collected in various communities without the authorisation of the indigenous communities and without authorisation by the Mexican authorities. (Castro Soto 2000, p.21). The criticisms of legitimacy and legality also refer to a more fundamental problem, namely the virtual non-existence of an adequate legal framework that recognises the strategic significance of biodiversity and regulates authorisations for biotechnological as well as the recognition of traditional knowledge (Castro Soto 2000, p.25 ff. The project director's view is summarised in Berlin and Berlin [2003]).

Disrespect for the political, philosophical and ethical principles of the community. The creation of an artificial representative of the communities concerned (PROMAYA) was not recognised by the opponents. The way ICBG-Maya interacted with the local population, and the way the benefit-sharing was supposed to be set up, did not take into account the specific culture, customs and organisational forms of the indigenous communities and their ways of making decisions. This also created tensions and conflicts among and within the communities. COMPITCH said it was time to "call upon all concerned, all those who in one way or another benefit or can benefit from our knowledge and from 
the usage of our plants, so that they are, finally, those who decide under which system these should be used" (COMPITCH, 2001).

Offences against traditional knowledge and health professionals. COMPITCH argues that bioprospection, commercial use and patent rights over knowledge and biological substances contradict the indigenous cosmo-vision (COMPITCH n.d.). Ana Valadez explains that "discussions around asking for a price in exchange for access does not make any sense. For indigenous communities, this form of monetary value does not exist. A plant has no price... Therefore, this discussion is completely sterile to us" Valadez 2005).

The organisational tradition of these communities is based on communitarian and shared use of knowledge and herbal remedies. The indigenous communities are not opposed to technological advancement but to the use that is made thereof (patent rights). COMPITCH states they are "not against the biotechnological aspects of the project but against the principles and conditions under which this project wanted to use our plants and our ancestral knowledge about them" (COMPITCH 2001.) They advocate a human logic for traditional medicine and reject the dynamics of the free market (Castro Soto 2000, p.25 ff).

Furthermore, COMPITCH claims that the profession of traditional indigenous healers, as well as the associated knowledge and practice, should receive more recognition and be better integrated into Mexican society, instead of being further isolated through the patenting of their knowledge and medical substances in laboratories of the North (Pérez 2000). Ana Valadez, spokesperson for COMPITCH, explains how traditional medical knowledge has been repressed from the times of the Conquista, when 300 THs were burned on the central square of San Cristóbal de las Casas by the Inquisition. Later on, the public health system further marginalised their professions. Only with liberalisation in the 1980s did the Mexican state discover indigenous medicine as an option to reduce funding for public health. This was the origin of the creation of $\mathrm{COMPITCH}$, which has meanwhile become independent from the state (Valadez 2005). The project would have contributed to the marginalisation of indigenous knowledge, as is apparent from the fact that indigenous knowledge, unlike biological substances, would not be eligible for royalties (Castro Soto 2000, p.31 ff.).

Economic and equity considerations. Not all communities that share Maya medicine were included in the scope of the project, and those that were included were not adequately informed. Furthermore, in his "Fifty reasons to reject ICBG-Maya", Castro Soto makes points such as "the salaries of the researchers are an insult to the poverty of the local peasants", or "the small amount of royalties to be obtained are not sufficient for 226,000 communities" (Castro Soto 2000, p.31 ff.).

\section{Outcome and prospects}

In the statement of COMPITCH after the suspension of the ICBG-Maya project, the organisation emphasised that unity and respect for the customs and culture of the indigenous communities were central in their successful struggle against the project. (When talking about the success of the resistance, one should, however, bear in mind that by mid-2000 the University of Georgia reported 
that they had already collected around 6000 species (Castro Soto 2000, p.13 ff). It remains open to question what happened to those results after the project was suspended.) Furthermore, it is only because the indigenous people still exist that medical plants are still known and at the disposal of those who need them (COMPITCH 2002b). Tradition and indigenity are thus explicitly claimed and valued. The successful opposition to ICBG-Maya is seen as a pioneering case and encourages similar action in other relevant regions (Boutorabi and Scheinemann 2003). In the defence of indigenous or traditional knowledge against privatisation and commoditisation, the case illustrates a different, more openly politicised strategy. Speaking for the organisation, Don Agripino Icó Bautista argued very clearly in terms of power and politics:

We want the suspension of the project and clear and truthful information for the community. We want a law proposed by the communities. The proposal by the healers and midwives is that we have control over our natural resources, which are our heritage and which should serve those who need them. Many researchers have tried to make particular benefits or benefits for the rich; because they have the power to extract this product. We want our own voice and our way in controlling our natural resources. (Don Agripino Icó Bautista and COMPITCH, quoted in Valadez 2000)

\section{Traditional knowledge - a political category}

As Mashelkar puts it, "one of the concerns of the developing world is that the process of globalisation is threatening the appropriation of elements of this collective knowledge of societies into proprietary knowledge for the commercial profit of a few" (Mashelkar in Correa 2001, p.18). We conclude that, whatever the choice of local communities regarding the protection of their indigenous knowledge, when facing the current IP regime and the power position of commercially driven global actors, the concept of traditional or indigenous knowledge itself becomes a political one. If the traditionality of knowledge can be reasonably questioned from an epistemological point of view, it would seem possible to claim rights and recognition for local communities in a highly controversial and economically relevant international arena.

As illustrated by the unsatisfying definitions in the literature and epistemological considerations, the term traditional is not suitable to characterise the epistemological status of the knowledge in question. What the term does describe is a position from which claims over knowledge, its use and protection, are formulated in a political battlefield. As the empirical examples show, some owners and users of knowledge need to explicitly claim their rights of access, use and intellectual ownership of certain forms of knowledge and associated practices in an increasingly internationalised arena where economically and politically powerful agents seek to appropriate such knowledge in order to commodify and use it commercially, thus restricting access and use. The knowledge in question is thus (re-)claimed by the protagonists themselves in pursuance of their own interests, either defensively, as a reaction to attempts by external agents to appropriate it, or offensively, in order to make commercial use of it themselves and to protect the knowledge in question in advance. We thus conclude by saying 
that from an epistemological perspective, the terms traditional or indigenous knowledge are questionable. The traditionality of knowledge is a political term that refers to the position and claims of adversary agents in the political battlefield created by capitalism. And yet, the possibilities of protection of indigenous knowledge as IP will require all knowledge to be recognised as important in its own right. Studying the relevance of a community's own protection mechanisms is no longer an option, but a necessity. Whether this is a possibility in the wake of globalisation is yet to be determined.

\section{Notes}

1. See contributions to the conference "Patented New World? '2005 and Stolpe 2001.

2. The topic of medical knowledge seems particularly relevant in the context of this discussion. Since colonisation, little value has been attached to traditional knowledge in the continents of the global South and much of it has been lost through the destruction of these continents' communities, their ways of life and their cultural values. However, in recent years scientific research has shown increasing interest in traditional knowledge because of its commercial value. This is particularly true in the domain of traditional medical knowledge, that is, medical practices based on the characteristics and use of natural and plant products to prevent and cure disease. While some components of such knowledge may be isolated from their context of origin and included in a different set of reasoning and practice, that is, modern science, other components cannot be used outside the communities in which they were originally practised, due to their close connection with broader belief systems, spiritual representations and cultural values. Hence the difficulties of an epistemological definition of the specificities of traditional knowledge as opposed to other types of knowledge.

3. Traditional knowledge has also played a vital role for millions in areas such as food security, agriculture, education and medical treatment. In particular, traditional medical knowledge serves the health needs of huge populations in poorer countries who might not have access to other types of health care, as well as in the EU and the USA where critics of conventional medicine favour alternative ways of prevention and healing. Its pragmatic significance has to be kept in mind in the course of the epistemological and political discussion in this article.

4. "Richard's analysis (1993, p.62) of knowledge as performance challenges the very idea of practices being grounded in an indigenous knowledge,' suggesting rather that the range of skills and strategies employed by farmers extend beyond simple applied knowledge into a 'set of improvisational capacities called forth by the needs of the moment.' He posits a 'theory of performance' which challenges the assumption that cultivation practices are evidence of fixed stock of knowledge form which techniques are drawn" (Ellen et al. 2000, p.17). For a concrete example of tacit knowledge or knowledge as performance see Fortier's (2005) in-depth study on bird-catching in the Ardennes region in France. 
5. This is for scholarly debate. For some years now, the more practically oriented approach in development policy has used the term traditional knowledge for development programs centred around empowering, bottom-up approaches and participation, especially so-called "farmer-firstapproaches" in development (for an overview see Sillitoe et al. 2005). This also involves the argument of oppositionality: "For some fifty years or more, the dominant model of development has been based on useful knowledge generated in laboratories, research stations and universities, and only then transferred to ignorant peasants... But not only has indigenous knowledge been grossly undervalued by western-trained 'scientific' managers in terms of its potential practical applications, when it was at last absorbed into 'scientific' solutions it was curiously insufficiently 'real' to merit any certain legal status or protection from the battery of patents and copyrights which give value and ownership to western scholarly knowledge and expertise" (Ellen et al. 2000, p.11).

6. “'Bio-piracy' has been defined as the process through which the rights of indigenous cultures to genetic resources and knowledge are 'erased and replaced for those who have exploited indigenous knowledge and biodiversity"' (Shiva et al. quoted in Correa 2001, p.XX). A different example of piracy is Uganda fighting to recover its rights over the backcloth. The backcloth is the original traditional dress of most of Ugandan groups, which was replaced by clothes made out of cotton. Central Ugandan peoples still use the backcloth to bury the dead in and it is also worn by their cultural leaders. Property rights were given to a European company over the backcloth a few years ago. While it was a public good, no one in Uganda had ever documented or tried to protect it from anyone who might have wanted to take advantage of that vacuum.

\section{References}

ALEXANDER, D. 2002. "Integrating intellectual property rights and development policy". Paper paper read at the conference of the Heinrich Böll Foundation "Die Zukunft der globalen Güter in der Wissensgesellschaft - auf der Suche nach einer nachhaltigen Politik zum Schutz des geistigen Eigentums" (The future of global goods in the knowledge society - in search of a sustainable policy for the protection of intellectual property) 8 November 2002, Berlin, available online at http http://www.wissensgesellschaft.org/themen/publicdomain/iprdevelopment.pdf [Accessed Nov. 09. BARREDA, A. 2000. "México: capital mundial de la biopiratería", La Jornada, 12 October 2000.

BERLIN, B. AND BERLIN, E. A. 2003. "NGOs and the process of prior informed consent in bioprospecting research: the Maya ICBG project in Chiapas, Mexico", International Social Science Journal, 10(4) 629-638.

BIACHI F. 2004. "New tradition for African health care", The Christian Science Monitor, available online at http://www.csmonitor.com/2004/1013/p06s02-woaf.html [Accessed Nov. 09]. Boutorabi, J. AND SCHEINEMANN, L. 2003. "Von PatentenP piraten und altem Pathis", GID 160 (Publication of Gen-Ethisches Netzwerk), Oct/Nov. 2003, available online at http://www.gen- 
ethisches-netzwerk.de/gid/160/thema/boutorabi/patenten-piraten-und-altem-pathos [Accessed Nov. 09].

CAstro Soto, J. 2000. "Pukuj - biopiratería en Chiapas", COMPITCH, San Cristóbal de las Casas, http://www.otrosmundoschiapas.org/analisis/BCEPCGMAYA.pdf (Accessed Nov. 09)

CBD CONVENTION ON BIOLOGICAL DiVERSITY (CBD) 1993. available online at http://www.cbd.int/convention/convention.shtml (Accessed Nov. 09).

CECEÑA, A. E. 2000. “Biopiratería y desarrollo sustentable?” Revista Chiapas 9, pp. 191-196, available at http://www.revistachiapas.org/No9/ch9.html (Accessed Nov. 09)

COMMISSION ON INTELLECTUAL PROPERTY RIGHTS (CIPR) 2002. "Independent commission finds intellectual property rights impose costs on most developing countries and do not help to reduce poverty". Press release, 12 September 2002, available online at http://www.biotechinfo.net/independent_commission.html [Accessed August 2007].

COMPITCH (n.d.) "Interview with Miguel Gómez Gómez and others”, available online at http://www.zapata.com/cciodh3/article-cciodh3-213.html [Accessed Nov. 09].

COMPITCH, 2001. "Palabra del COMPITCH con motivo de la cancelación del proyecto de bioprospección del consorcio ICGB Maya, San Cristóbal de las Casas”, 29 November, available online at http://www.prodiversitas.bioetica.org/prensa13.htm [Accessed October 2007].

COMPITCH, 2002a. "Comunicado", 21 April, San Cristóbal de las Casas, available online at http://chiapas.laneta.org/noticias/compitch20020521.htm [Accessed October 2007].

COMPITCH, 2002b. "Principios y reglas mínimas". San Cristóbal de las Casas, 19 May, available online at http://chiapas.laneta.org/noticias/compitch-reglamento.htm [Accessed October 2007].

CORREA, C. 2000. "Integrating public health concerns into patent legislation in developing countries". Geneva: South Centre, available online at http://www.southcentre.org/index.php?option=com_content\&task=view\&id=69\&Itemid=67 (Accessed Nov. 09)

CORREA, C. 2001. "Traditional knowledge and intellectual property: issues and options surrounding the protection of traditional knowledge". Discussion paper. The Quaker United Nations Office, Geneva, available online at http://www.quno.org/geneva/pdf/economic/Discussion/TraditionalKnowledge-IP-English.pdf (accessed Nov. 09].

CORREA, C. 2002. "Managing the provision of knowledge: the design of intellectual property laws". In: Kaul, I., Conceicao, P., Le Goulven, K.and Mendoza, R. U. eds Providing global public goods. New York: Oxford University Press: 410-430.

DEARDORFF, A. 1992. "Welfare effects of global patent protection", Economica 59(233) 35-51.

EllEN, R. AND HARRIS, H. 2000. "Introduction”. In: Ellen, R., Parkes, P and Bicker, A. eds Indigenous environmental knowledge and its transformations: critical anthropological perspectives. Amsterdam: Taylor \& Francis: 1-35. 
ELLEN, R., PARKES, P. AND BICKER, A. eds 2000. Indigenous environmental knowledge and its transformations: critical anthropological perspectives. Amsterdam: Taylor \& Francis.

EROSION, TECHNOLOGY AND CONCENTRATION (ETC) GROUP 2001. "US government's \$2.5 million biopiracy project in Mexico cancelled. Victory for indigenous peoples in Chiapas", News release, 9 November 2001, available online at http://etcgroup.org/en/node/232?pub_id=232 [Accessed October 2007].

FORTIER, A. 2005. "Des savoir locaux insaisissables? L'exemple de la tenderie aux grives en Ardenne", VertigO - La revue en sciences de l'environnement, 6(3) 30-39.

HounTONDJ, P. J. 1994. “Démarginaliser”. In: Hountondji, P. J. ed. Les savoirs endogènes: pistes pour une recherche. Dakar: CODESRIA: 1-37.

INTERNATIONAL BUREAU OF WIPO 2002. "Information note on traditional knowledge", 21 and 22 January 2002, available online at http://www.wipo.int/arab/en/meetings/2002/muscat_forum_ip/iptk_mct02_i3.htm [Accessed August 2007].

KRAAK, A. 2000. Changing modes: new knowledge production and its implications for higher education in South Africa. Pretoria: HSRC.

OXFAM, 2002. "Intellectual property and the knowledge gap". Contribution paper to World Social Forum, Porto Alegre, Brasil, 31 January to 5 February, available online at www.oxfam.org.uk/what_we_do/issues/trade/trips_wsf2002.htm [Accessed June 2005].

NYIKA A. 2007. "Ethical and regulatory issues surrounding African traditional medicine in the context of HIV/AIDS", Developing World Bioethics, 7(1) 25-34.

PANAGARIYA, A. 1999. "TRIPS and the WTO: an uneasy marriage”. Presentation at the WTO on 20 July 1999, available online at http://129.3.20.41/eps/it/papers/0309/0309002.pdf (Accessed Nov. 09) PARDEY, P. G. AND WRIGHT, B. D. 2001. "Intellectual property rights and agricultural R \& D”, Brief 8, International Food Policy Research Institute, available online at http://econpapers.repec.org/paper/fpr2020fo/8.htm [Accessed August 2001].

SILlitOE, P., DIXON, P. AND BARR, J. 2005. Indigenous knowledge inquiries: a methodological manual for development. Dhaka: ITDG.

PÉREZ, U. M. 2000. "Llaman en un foro a debatir sobre un código de ética”. La Jornada, 17 September.

PotTier, J., BiCKer, A. AND Sillitoe, P. 2003. Negotiating local knowledge. London: Pluto Press. STOLPE, M. 2001. "Weltweiter patentschutz für pharmazeutische innovationen: gibt es sozialverträgliche alternativen?” Kiel working papers, no. 1079, available online at http://ideas.repec.org/p/kie/kieliw/1079.html [Accessed 29 October 2009].

TANSEY, 2002. "Patenting our food future: intellectual property rights and the global food system", Social Policy and Administration, 36(6) 575-592. 
Tourism, Hospitality, Sport Education and Training Authority (THETA) 2005. Annual report. Unpublished.

Uganda National Council of Science and Technology (UNCST) 2006. "National indigenous knowledge policy for Uganda" (final draft). Unpublished document, Kampala VALADEZ, A. 2000. "Nuestros recursos, nuestro saber, inalienables", La Jornada 14 August, available online at http://www.jornada.unam.mx/2000/08/14/oja-compitch.html [Accessed October 2007]. VALADEZ, A. 2005. "Es wurde nie gerecht geteilt - interview mit Ana Valadez", GID 168, Febrary/March, pp. 47-5,1 available online at http://www.gen-ethischesnetzwerk.de/GID168_Valadez (Accessed Nov. 09) COMMITTEE ON INTELLECTUAL PROPERTY RIGHTS (CIPR) 2005. "Integrating intellectual property rights and development policy", available online at at www.iprcommission.org, [Accessed 30 October 2009].

CIPR 2002. "Independent Commission finds IP rights impose costs on most developing countries and do not help reduce poverty", press release 12 September, available online at http://www.biotechinfo.net/independent_commission.html [Accessed 30 October 2009].

COMMISSION ON INTELLECTUAL PROPERTY RIGHTS (n.d.) "Public health and innovation of the world health organization", available online at http://www.who.int/intellectualproperty/studies/en/ [Accessed August 2007].

Council of Scientific \& Industrial Research (CSIR)/Department of Ayurveda, Yoga \& Naturopathy, Unani, Siddha and Homeopathy (AYUSH): Traditional Knowledge Digital Library, available at http://www.tkdl.res.in/tkdl/langdefault/common/Home.asp?GL=Eng (Accessed Nov. 09) LEWIS \& CLARK LAW SCHOOL (n.d.) "International environmental law project: genetic resources", available online at http://www.lclark.edu/org/ielp/nijar2.html [Accessed 30 October 2009]. INTERNATIONAL COOPERATIVE BIODIVERSITY GROUPS (n.d.) Home page, available online at http://www.icbg.org/ [Accessed 30 October 2009].)

ORganisation of INDigenOUS HEALERS OF THE STATE OF CHIAPAS (OMIECH) (n.d.) home page, available online at www.medicinamaya.org [Accesssed 30 October 2009]).

HEINRICH BÖLL STIFTUNG FOUNDATION. 2005. "Patented new world? "Geistiges Eigentum” versus Entwicklung und Menschenrechte im Nord-Süd-Konflikt Internationale Fachtagung" Conference coorganized with Forschungs- und Dokumentationszentrum Chile-Lateinamerika (FDCL), held in Berlin, 2-3 June, available online at http://www.wissensgesellschaft.org/themen/publicdomain/tripstagung.html [Accessed July 2007). 